\title{
The TARES Test: Five Principles for Ethical Persuasion
}

\author{
Sherry Baker \\ Brigham Young University \\ David L. Martinson \\ Florida International University
}

\begin{abstract}
$\square$ Whereas professional persuasion is a means to an immediate and instrumental end (such as increased sales or enhanced corporate image), ethical persuasion must rest on or serve a deeper, morally based final (or relative last) end. Among the moral final ends of journalism, for example, are truth and freedom. There is a very real danger that advertisers and public relations practitioners will play an increasingly dysfunctional role in the communications process if means continue to be confused with ends in professional persuasive communications. Means and ends will continue to be confused unless advertisers and public relations practitioners reach some level of agreement as to the moral end toward which their efforts should be directed.

In this article we advance a five-part test (the TARES test) that defines this moral end, establishes ethical boundaries that should guide persuasive practices, and serves as a set of action-guiding principles directed toward a moral consequence in professional persuasion. The TARES Test consists of five principles: Truthfulness (of the message), Authenticity (of the persuader), Respect (for the persuadee), Equity (of the persuasive appeal) and Social Responsibility (for the common good). We provide checklists to guide the practitioner in moral reflection and application of TARES Test principles.
\end{abstract}

Individuals active in some area of professional persuasive mass communication - that is, advertising, public relations, and so forth-frequently have a difficult time defending what it is they do from a societal, common good, and ethical perspective, in their own minds as well as in their conversations with others.

Defenders-apologists—for advertising and public relations, although not denying that ethical considerations have been a problem, also contend that critics often overstate the case. Speaking specifically to the question of societal value, advertisers frequently contend that without advertising the American free enterprise system simply would not exist. In this they echo the rhetoric of U.S. Supreme Court Justice Harry Blackmun in his opinion for the court in the landmark Virginia Board of Pharmacy v. Virginia Citizens 
Consumer Council (1976) case that afforded commercial advertising limited First Amendment protection. In his opinion in that case Justice Blackmun wrote

Advertising, however, tasteless and excessive it sometimes may seem, is nonetheless dissemination of information as to who is producing and selling what product, for what reason, and at what price. So long as we preserve a predominately free enterprise economy, the allocation of our resources in large measure will be made through numerous private economic decisions. It is a matter of public interest that those decisions, in the aggregate, be intelligent and well informed. To this end, the free flow of commercial information is indispensable. (p. 765)

Legendary public relations scholar Scott Cutlip (1994) presented a similar societal justification for public relations when he asserted that "the social justification for public relations is to ethically and effectively plead the cause of a client or organization in the free wheeling forum of public debate" (p. xii). Cutlip maintained that in a democratic society the practitioner serves the common good by helping to bring about a process in which "every idea, individual, and institution ... [has] a full and fair hearing in the public forum" (p. xii).

\section{Ethical Problem in Persuasive Communications}

It seems clear that proponents believe the persuasive "professions" can serve the public interest and that persons active in those professions can be ethical. Unfortunately, the "can" too often does not translate into a reality of fact. That is, although proponents argue advertising can serve the economic or social system by providing important consumer information, too frequently it operates dysfunctionally by providing misinformation, inflating the cost of goods and services, and inducing individuals to make purchases that are not in either their short- or longterm interest.

The same is true in regard to public relations. Although many practitioners will insist Cutlip (Cutlip, Center, \& Broom, 1994) is correct in asserting that practitioners can serve the public interest by helping to make various points of view articulate in the marketplace of ideas, in fact those same practitioners too frequently serve to disrupt that marketplace by serving special interests at the expense of the common good (p. 133). Furthermore, instead of providing useful information, practitioners frequently "clutter ... [the] already-choked channels of communication with the debris of pseudoevents and phony phrases that confuse rather than clarify" (Cutlip et al., 1994, p. 133). 
One needs to ask, Why? Why do the persuasive professions at least appear to evoke in persons a proclivity toward acting in a less than ethical manner and in ways that are detrimental to the common good or public interest? Critics argue that such a response is intrinsic to the very nature of much of persuasive communication. That is, efforts to persuade-despite all the efforts at rationalization-can not really be differentiated from manipulation, coercion, propaganda, or all of these.

More supportive of efforts to persuade is the work of Andersen (1978) who defined ethical persuasion as "a communication activity that unites people ... [while it] permits maximum individual choice" (p. 3). For Andersen, ethical persuasion centered around an effort "to effect a desired voluntary change in the attitudes and/or actions of" (p. 7) those to whom particular persuasion efforts are directed. For communication ethicists Jaksa and Pritchard (1994), Andersen's emphasis on voluntary change was critical. Jaksa and Pritchard stated

... [this emphasis on voluntary change] in the person being persuaded ... distinguishes persuasion from indoctrination and coercion, which do not allow significant choice. But it also suggests that ethically acceptable modes of persuasion do not rely on deceptive manipulative tactics.... [Jaksa \& Pritchard] support those forms of persuasion that show respect for individuals as capable of making significant choices ... those capable of rational choice are respected only if manipulative and deceptive tactics are avoided. (p. 76-77)

\section{"The advantage of a lie without telling a literal untruth"}

It has been suggested that to allow for voluntary change, the persuader must provide for something at least approaching what Klaidman and Beauchamp (1987) termed substantial completeness - "that point at which a reasonable ... [person's] requirements are satisfied" (p. 35). Although ethics may not dictate that the persuader provide a scientifically verifiable summation of a particular issue, one can insist that such efforts "be directed toward genuinely informing ... [others] —not creating false impressions, whether or not what is communicated might be literally, in at least some fashion, true" (Martinson, 1996-1997, p. 44).

It is precisely at this point that problems begin to surface. Advertising and public relations practitioners too often use "torturous linguistic contortions" to achieve what Gaffney suggested was "the advantage of a lie without telling a literal untruth" (Martinson, 1996-1997, p. 43). The case study law books are filled with such examples. Certainly one of the classics 
in this regard is the Federal Trade Commission order that "ITT Continental Baking Company ... correct a false impression created by a long-term series of advertisements for the company's Profile bread" (Middleton \& Chamberlin, 1994, p. 322). Profile advertising had implied

That consumers could lose weight by eating Profile bread because it contained fewer calories than other breads. Actually, Profile bread contained the same number of calories per ounce as other breads. Therefore, if a person kept a better figure while eating ITT Continental's bread, it was because Profile bread was sliced thinner. (Middleton \& Chamberlin, 1994, p. 322)

Is it any wonder that advertisers and public relations practitioners are viewed in such a negative light when one recognizes that examples such as the Profile "fewer calories" campaign are too often more reflective of behavior that is normal for the industry rather than exceptional? Advertisers and public relations practitioners are distrusted because the public-with good reason-has come to recognize that too frequently the goal in persuasive communication centers around exploiting them in a manner that is, in fact, "detrimental to ... [the public's] own preferences, interests, or well being" (Jaksa \& Pritchard, 1994, p. 76).

Defining the problem, of course, is less difficult than advancing-from an ethics perspective- an answer. Surely there would not be so much unethical persuasive communication if there were not some benefit in engaging in such wrong actions. Many feel they are "forced" to use less than ethical means because the use of such means are essential to achieving the desired end. Chided for their use of stereotypes, for example, many in advertising are likely to respond "Gee, I'd really like to avoid these stereotypes, but I've got to use them to survive" (DeFleur \& Dennis, 1998, p. 337).

\section{The "Relative Last End" of Professional Communications}

One will never be able to articulate a practical means to achieving at least something approaching a level of minimally acceptable ethical behavior in persuasive communications until there is greater agreement as to what is that last end toward which persuasive communication is directed.

It is essential to note, in this context, that what is being considered here is a relative last end - but, nevertheless, something beyond increased sales or an improved corporate image. When Cutlip (1994), for example, spoke about assisting clients in an effort to inject their views into the marketplace of ideas, there is an unstated assumption that there is an end that will be achieved in that process. Hopefully, that end goes beyond increased profits for the particular organization the practitioner represents. 
For the philosopher, "a thing is intended either for its own sake or for the sake of something else" (Fagothey, 1976, p. 85). There have, of course, been "pitched battles" between teleologists who argue an act should be judged ethical or not based on its consequences, and deontologists who argue an action must be judged ethical or not according to the means utilized to achieve the desired end. Most would agree, however, with Fagothey that "a means always supposes an end" (p. 85). More specifically

... [A means] is called a means precisely because it lies on a mean, or middle, position between the agent and the end, and its use brings the agent to the end. The same thing may be both means and end in different respects, for it may be sought both for its own sake and for the sake of something further. This is called an intermediate end, and there may be a long series of such intermediate ends, as when we want $A$ in order to get B, B in order to get $C, C$ in order to get D, and so on. (Fagothey, 1976, p. 85)

That is why one speaks of a relative last end as the goal of persuasive communications in the immediate context. In a strict philosophical sense, what is being discussed is an intermediate end-as contrasted with an ultimate or absolute last end. It is, of course, well beyond the scope of this particular effort to consider questions germane to what may be the ultimate or absolute last end of those engaged in persuasive communications-that must be left to philosophers and theologians. What is of primary concern here is examining that relative last end toward which a discussion of applied ethics in the persuasive communication can and should be directed.

The immediate end in some forms of persuasive communication is readily identifiable. Wells, Burnett, and Moriarty (1992) stated that the goal (end) of product advertising is "to inform or stimulate the market about the sponsor's product(s). The intent is clearly to sell a particular product, to the exclusion of competitors' products" (p. 13).

The immediate goal (end) of public relations, on the other hand, is subject to some debate even among practitioners. Cutlip (1994), for example, has consistently identified the practitioner as an advocate-insisting that "the advocate's role is essential in a democracy that must be responsive to the public and dependent on the reconciliation of public and private interests in a mutually rewarding manner" (p. xii). Grunig and Hunt (1984), on the other hand, have advanced what they define as a "two-way symmetric" model of public relations that has as a "goal ... [facilitating] mutual understanding between organizations and their publics" (p. 22).

The Grunig and Hunt (1984) "two-way symmetric" model, in fact, is useful in the context of defining a "relative last end" in all forms of persuasive communication because it is stated in terms that at least begins to 
move beyond egocentricity — and surely "overcoming, or at least reducing, egocentricity is an essential element" in the cultivating of persons who will engage in what reasonable persons would define as ethical persuasion (Jaksa \& Pritchard, 1994, p. 94).

It is for this reason that the relative last end in persuasive communications must not be defined in terms of increased sales or increased profitability or visibility for an organization or client. That is not to suggest that efforts directed toward increased profitability or visibility are illegitimate per se. It is to suggest, however, that the persuader wishing to be ethical must always keep in mind that increased sales or increased visibility are nothing more than a means to some more important social and individual end. If not, persuaders inevitably will begin to embrace something approaching social Darwinism in which the goal too often is to succeed at all costs - or at least to succeed through the use of any means that do not violate the letter of the law.

The last end in persuasive communication (relative to the context of this discussion) must center around respect for that individual to whom the particular persuasive effort is directed. Any persuasive effort must be directed toward providing information that will enable the person to whom it is directed, in Andersen's (1978) earlier cited words, the freedom to make a voluntary choice (p. 7). Although the short-term-or immediate-goal, in the case of advertising for example, may well be increased sales, the ethical persuader will only utilize those messages and methods that demonstrate genuine respect for those to whom the particular advertisement is directed.

Genuine respect dictates that the persuader place the interests of persons to whom a particular persuasive effort is directed before his or her (the persuader's) narrowly defined self-interest. It means, in fact, that the persuader must ethically evaluate his or her efforts from a relative last end perspective, which views a particular persuasive effort as

Assisting the receiver in attaining that which is already implicitly ... in the receiver's interest.... [the persuader] must communicate truthful and substantially complete information ... [in a context] that will enable the receiver to make a rational decision to accept or reject that which is being put forth. (Martinson, 1996-1997, pp. 44-45)

That is not to say that all efforts at persuasion must be ethically evaluated from a coldly analytical and scientifically objective perspective. Jaksa and Pritchard (1994), in fact, made an important point when they pointed out that "rational argument is not the only morally acceptable form of persuasion" (p. 77). They were quick to add, however, that "even when evidence or proof is not available, those capable of rational choice are respected only if manipulative and deceptivetactics are avoided" (Jaksa \& Pritchard, 1994, p.77). 
This is true because persuaders are engaged in acts of communication and any effort to communicate can be judged as ethical only to the degree with which it provides, as a relative last end, genuinely truthful information. One who communicates false, misleading, or deceptive information in a serious circumstance, from a moral philosophy perspective, does wrong because to do so perverts the very purpose of speech (communication). Certainly society would quickly come to a grinding halt were deception to become the norm. Fagothey (1976) made this point succinctly when he stated

By nature ... [each man and woman] is a social being, and the gift of speech is perhaps the chief means by which ... [our] social life is carried on. Like all other gifts, speech may be used or abused. Thus truthfulness is good and lying is wrong.... [To wrongfully deceive] is morally wrong because it is an abuse of the natural ability of communication, because it is contrary to ... [an individual's] social nature, which requires mutual trust, ... and because it debases the dignity of the human person, whose mind is made for truth. (p. 241-242)

In final analysis, is that not why advertising and public relations practitioners are viewed so negatively by a large percentage of the population? People distrust "professional" persuaders because they believe-with good reason - that too often those persuaders are attempting to manipulate them in ways that are "detrimental to ... [their] own preferences, interests, or wellbeing" (Jaksa \& Pritchard, 1994, p. 76). Advertisers and public relations practitioners are distrusted because their goals (relative last ends) are defined not in terms of the interests or well-being of those to whom their particular persuasive efforts are directed. In fact, too often their (the persuaders') efforts, as noted, are directed toward goals (ends) that run counter to the interests or well being of those to whom those efforts are directed.

Those engaged in efforts to persuade through advertising and public relations will begin to demonstrate genuine respect for others only when they begin to "demonstrate that they can view a situation through the eyes of listeners as well as their own" (Jaksa \& Pritchard, 1994, p. 78). If professional persuaders make an effort to view their work through the eyes of "significant others," surely they will be more likely to avoid the temptation to lie without lying, to be deceptive without telling a material lie, to secure the advantage of a lie without making a literal false statement (Gaffney, 1979, p. 268).

\section{Moral Myopia in The Culture Of Professional Persuasive Communications}

Ethics (moral philosophy) is a subject that primarily is not concerned with increased profits or increased company visibility. It is, rather, concerned with what one ought to do-or ought not to do (Fagothey, 1976, p. 
3). One might suggest that one can "call those actions right which ... [one] ought to do, and those actions wrong which ... [one] ought not to do" (Fagothey, 1976, p. 2). Ethics further asks that one be able to justify his or her actions from the perspective of others- " to attempt to justify ... is to offer reasons in support of ... [an action that] can be found acceptable to anyone capable of rationally considering ... [that action], not just to oneself" (Jaksa \& Pritchard, 1994, p. 108).

Noted contemporary ethicist Bok (1989) agreed that one must be able to justify his or her actions from the perspective of others-what she terms reasonable persons (p. 91). "To justify," Bok (1989) argued, "is to defend as just, right, or proper, by providing adequate reasons" (p. 91). She insisted that it is not enough to be able to justify one's actions to one's self. Consulting one's informed conscience, of course, is essential to ethical decision making. Bok (1989) noted, however, that conscience can "be very accommodating and malleable" (p. 94). Those who would engage in unethical conduct often "have a ... [comparatively easy] time in justifying their behavior so long as their only audience is their own conscience or their selfappointed imaginary onlooker" (Bok, 1989, p. 94-95).

\section{One's informed conscience, of course, is essential to ethical decision making.}

The key, according to Bok (1989), is to move to a level of "public justification" (p. 97). The individual engaged in a particular persuasive communication effort, for example, would be required-hypothetically-to be willing to "try to convince an audience of representative people that" his or her particular communication efforts were justified (Jaksa \& Pritchard, 1994, p. 107). Bok (1989) called this "publicity" (p. 97).

A willingness to meet this "test of publicity" would most likely eliminate a considerable portion of what reasonable persons would define as unethical conduct in persuasive communication. A willingness to meet such a test would also indicate that those engaged in persuasive communication did respect those to whom particular communication efforts were directed the standard that is advanced here.

Application of this test of publicity can perhaps be made more clear by citing the debate surrounding the case of an automobile manufacturer who advertised (promoted) its product "by comparing the quietness of its car to that of a glider ... [while] not saying that a glider is noisy in flight" (Pember, 1981, p. 414). A reasonable person would most likely judge that the advertiser was attempting to use literal truth to manipu- 
late potential customers into buying its particular model. (The great majority of persons have never been in a glider and would naturally assume that a powerless aircraft, high above the hustle and bustle of the working world, must be a virtual citadel of restful peace and tranquility.) That same reasonable person, therefore, would likely conclude that the advertiser was not showing respect for those to whom the communication was directed. In short, that advertiser would fail Bok's (1989) test of publicity.

Similar was the case of the public relations practitioner working for a large conglomerate (Montgomery, 1978, p. 14). He was quoted as saying "It's so damn easy to massage the numbers" (Montgomery, p. 14). Why would one want to "massage numbers"? In the specific instance, he said, because "his company was able to show in the front of its annual report ... that per share earnings were as good as management had predicted they would be" (Montgomery, p. 14). In fact, one "had to wade through some fine print and the heavy financial tables way in the back of the report" (Montgomery, p. 14). At that point, one would find "that earnings were down sharply" (Montgomery, p. 14).

In the process, the macroethical question has been ignored.

A problem for persuasive communication centers around the fact that, despite all the rhetoric to the contrary, unethical conduct-conduct that does not show respect for those to whom particular communications are directed-continues to be far too often the norm. It continues to be the norm because those engaged in particular facets of persuasive communication-including practitioners and educators responsible for the instruction of future practitioners-have too often viewed ethics in microterms. Too often the focus has been on whether or not a particular persuasive effort is ethical or unethical. In the process, the macroethical question has been ignored. That is, what is that relative last end toward which such persuasive communication is directed?

So long as those in persuasive communication continue to focus on the individual "sins" of practitioners and not the broader question of why such sins are so prevalent, the level of ethical conduct in advertising and public relations will not be advanced. People do not so generally and broadly distrust those in persuasive communications because occasionally an advertiser or public relations practitioner will engage in less than ethical conduct. They distrust persuasive communicators-generally and broadly-because they fear those in the field do not respect them as individuals and are interested only in achieving immediate and narrowly defined self-interested goals or objectives-goals or objectives that often are not in the interest of those to whom persuasive communication is directed.

It is the broader working place culture of the persuasive professions that is the major problem, and not so much the individual acts-however reprehensible they may be-of particular practitioners. Because of a cultural 
myopia that is so pervasive in persuasive communication, practitioners and educators "have not been sufficiently attentive to a need to transcend a narrowly defined personalistic vision" (Martinson, 1996, p. 20). One might suggest that to this point far too "much of the effort ... [to define ethical behavior in persuasive communications has been] spent paying attention to the ethical trees ... [when it] would be more profitably expended if it were focused on the ethical forest from which the trees cannot be separated" (Martinson, 1996, p. 4).

It may, for example, help to soothe a troubled conscience when a practitioner active in advertising or public relations chooses to make a public "confession" as to particular unethical transgressions he or she is guilty of vis-à-vis acts of persuasion. Such an individual may, in fact, be entitled to a certain level of absolution providing they display genuine contrition. Unless, however, a greater number of those active in persuasive communication are willing to confront the broader working place culture question as to why such acts are so prevalent, ethical conduct will not significantly improve because individual acts, as noted, do not take place in a professional or cultural vacuum.

\section{Moral End of Persuasive Communication}

Those active in some aspect of persuasive communication would do well to read and contemplate Victor Hugo's (1862/1997) classic novel, Les Miserables. In that novel, Hugo schooled the reader-perhaps as well as any novelist in history-that justice, particularly social justice, cannot be defined so much in terms of individual acts, but rather in terms of broader principles. A man who emerges in the novel as an intrinsically good man, Jean Valjean, is convicted of stealing bread. Later, when he escapes, he is pursued in a relentless manner by a cold, unsympathetic and legalistic policeman-Javert.

The lesson is clear. Valjean emerges as a good man because he has a better understanding of that end toward which one's individual acts are directed. Although the act of stealing another's property under ordinary circumstances is wrong, property is but a means to an end. Traditional ethics consistently held, in fact, that one-under extreme circumstances-was entitled to steal food.

It is again a matter of putting means and ends into proper perspective, and this is a particularly important point where persuasive communications are concerned. If means continue to be confused with ends in professional persuasive communications, there is a very real danger that advertisers and public relations practitioners will play an increasingly dysfunctional role in the communications process. Means will continue to be confused with ends unless advertisers and public relations practitioners 
reach some level of agreement as to that relative last end toward which their efforts should be directed.

In this article we argue that the end must be formulated in a way that places an emphasis on respect for those to whom particular persuasive communication efforts are directed. The advertiser may legitimately hope to increase sales of a particular model of automobile, and the public relations practitioner may legitimately wish to improve the image of a particular client whose business practices have come under assault-but in the attempt to achieve this immediate end, advertisers and public relations practitioners act unethically if they utilize methods intended more to manipulate, exploit, or both, listeners and persuadees than to respect them. They act unethically because no professional persuasive communication effort is justified if it demonstrates disrespect for those to whom it is directed.

\section{Search for Guiding Principles in Persuasion}

Communications scholars, practitioners, and observers long have sought to articulate guiding ethical principles for their work. "Ethical principles [for professionals] have proven useful in identifying the conflicting responsibilities in a moral dilemma, bringing clarity to moral thinking, and providing a shared language for discussion" (Fitzpatrick \& Gauthier, 2000). Lambeth (1986), for example, has identified for the ethical practice of journalism the principles of truth telling, justice, freedom, humaneness, and stewardship. The Code of Ethics of the Society of Professional Journalists (SPJ) discusses the principles of truth, minimizing harm, independence, and accountability (SPJ, 1996). The Member Code of Ethics of the Public Relations Society of America (PRSA) discusses the principles of advocacy, honesty, expertise, independence, loyalty, and fairness (PRSA, 2000); the National Communication Association's (NCA's) Credo for Ethical Communication lists the principles of human worth and dignity, truthfulness, fairness, responsibility, personal integrity, and respect for self and others (NCA, 1999); and the International Association of Business Communicators (IABC) articulates the principles of human rights, rule of law, sensitivity to cultural norms, truthfulness, accuracy, fairness, respect, and mutual understanding (IABC, 2000). A quite different source, the Pontifical Council for Social Communications, proposed three moral principles for the ethical practice of advertising: truthfulness, dignity of the human person, and social responsibility (Pontifical Council for Social Communications, 1997).

Christians (personal communication, October 14, 2000) has called for establishing a set of prima facie duties (principles) specifically for commercial information (which is inherently utilitarian and consequentialist). 
To best serve the public interest in an ethical manner, commercial information needs an ethics of duty to replace its consequentialism. In ethical theory, duty ethics is the radical alternative to utilitarianism.... I see this theory as the best framework for insuring that commercial information operates in the public interest.... Rather than patch up utilitarianism, or try to make it work-if we adopt a new ethical theory we will transform our profession. (Christians, 1999.)

Our goal in this article was to articulate a set of prima facie principles for persuasion that would operationalize ethical theory, facilitate ethical thinking, be useful pedagogically, and engender the ethical practice of persuasion.

\section{TARES Test: Five Principles for Ethical Persuasion}

We propose a five-part test of prima facie duties that defines the moral boundaries of persuasive communications and serves as a set of actionguiding principles directed toward a moral consequence in persuasion. We suggest that these five principles, taken together, comprise the legitimate end of persuasive communications. Each principle focuses on a different element or component of the persuasive act from the perspective of the communicator. (The test does not address the ethical obligations of the receiver of the persuasive message.) We first present each of the principles individually, and then discuss them together as a set of prima facie duties.

The TARES Test is an acronym that consists of the five principles: Truthfulness (of the message), Authenticity (of the persuader), Respect (for the persuadee), Equity (of the persuasive appeal) and Social Responsibility (for the common good; see Figure 1).

In our discussion, we include reflection tables that are meant to communicate the essence of each principle and to stimulate thinking about its application. The TARES Test consists only of the five principles; the questions in the reflection and applications tables are only examples of issues to think about in applying TARES Test principles. The questions can be modified as needed to shed light on various and specific persuasive contexts faced by the practitioner.

\section{Truthfulness (of the Message)}

The first principle in the TARES Test focuses on the persuasive message and requires that it be not only true, but truthful.

Among the consistent themes in Bok's (1989) writing is that deception causes harm to individuals and to society, that "trust is a social good to be protected" (p. 26), and that deception undermines that trust. Bok (1989) equated deceit with violence, "the two forms of deliberate assault on human beings" (p. 18). 


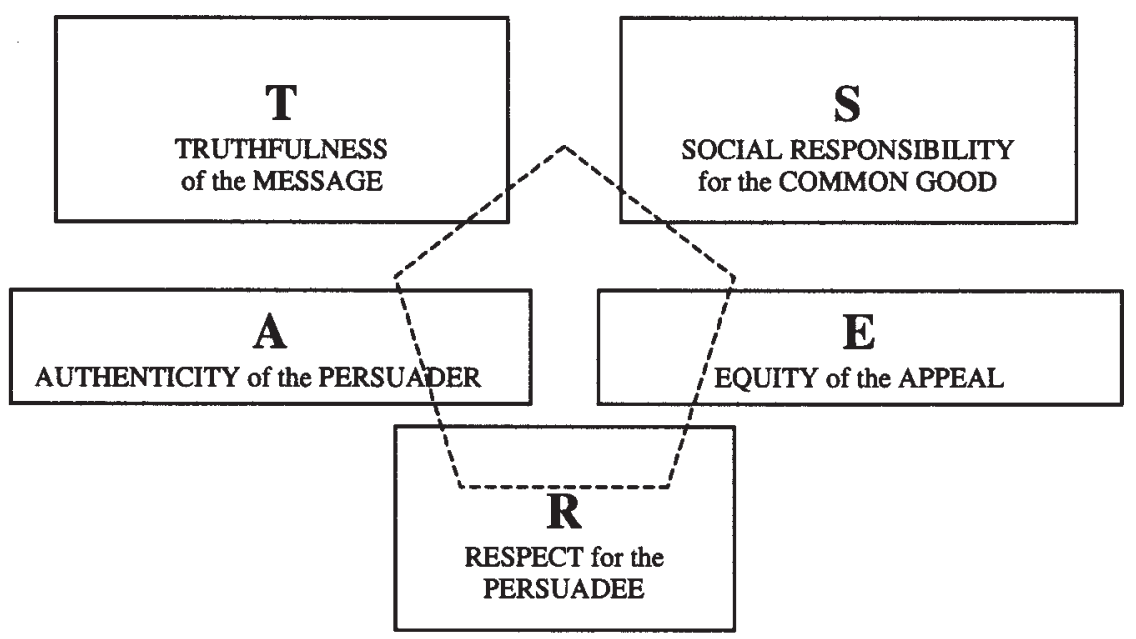

Figure 1 The TARES Test: Five principles for ethical persuasion.

All societies have stressed certain basic injunctions against at least a few forms of wronging other people chief among these "force and fraud," or violence and deceit. From the Ten Commandments to Buddhist, Jain, Confucian, Hindu, and many other texts, violence and deceit are most consistently rejected, as are the kinds of harm they make possible, such as torture and theft. (Bok, 1995, p. 15)

Just as violence takes power and control away from the one assaulted and gives that power and control to the assaulter, so does deception. People rely on information from others to make their choices in life, large or small. Lies distort this information, alter the choices of the deceived, and injure and lead him or her astray. In deception, then, as in violence, there are issues of power, of harm, and of violation of agency. From this perspective, to persuade others through deceptive messages is harmful to persuadees and undermining of their trust, and should be regarded with the same seriousness as an act of violence.

Truthfulness in the TARES Test is a broader standard than literal truth. It is possible to deceive without literally lying. The Principle of Truthfulness requires the persuader's intention not to deceive, the intention to provide others with the truthful information they legitimately need to make good decisions about their lives.

Table 1 provides a list of questions that professional persuasive communicators might ask themselves to guide their moral reflection in application of the Principle of Truthfulness of the Message. 
Table 1

Truthfulness (of the Message)

Is this communication factually accurate and true, and also truthful? Does it deceive others either overtly or covertly? Does it lead people to believe what I myself do not believe? (Bok, 1989, p. 13)

Is this communication consistent with open, sincere, and honest communication? Is it responsive to the persuadees' human need to have truthful information to inform their life decisions?

Would I feel that this communication was truthful and nondeceptive if communicated to me in this context?

Is this communication substantially complete? Does it satisfy a reasonable person's requirements for information in this situation? (Klaidman \& Beauchamp, 1987, p. 35)

Have comparisons between alternatives been presented in an undistorted and truthful manner? (Cooper \& Kelleher, 2000)
Has this appeal downplayed relevant evidence? (Cooper \& Kelleher, 2000)

If this message communicates only part of the truth, what are my justifications for disseminating this selective (incomplete) truth? Are my omissions meant to deceive? (Deaver, 1990, pp. 168-177)

Am I creating a false image or a false impression with selective information? Will the people receiving this message feel they have been deceived if later they learn the whole truth?

Is the information withheld needed by the audience for their own choices and actions? Will not having this information result in any harm? (Fitzpatrick \& Gauthier, 2000)

Will people have reason to question my honesty and trustworthiness as a result of this communication?

What can I do to ensure that this persuasive message is truthful?

\section{Authenticity (of the Persuader)}

The Principle of Authenticity in the TARES Test centers on issues related to the persuader. Authenticity is a complicated and variously defined concept, grounded in the philosophical literature of existentialism, that has "develop[ed] in many branches" (Taylor, 1991, p. 66). For purposes of the TARES Test, we carve out a particular connotation for authenticity that combines a cluster of related issues including integrity and personal virtue in action and motivation; genuineness and sincerity in promoting particular products and services to particular persuadees; loyalty to appropriate persons, causes, duties, and institutions; and moral independence and commitment to principle.

In broad terms, as envisioned here, authenticity is about discovering and expressing oneself, self-development, being true to oneself, and "finding the design" of one's own life oneself (Taylor, 1991, pp. 67-68). However, it relates also "to issues of self in situation" (Langan, 1992, p. 3). It is 
"the opposite of narcissistic" (Langan, 1992, p. 12), and assumes that one finds "genuine fulfillment" only in something that has significance independent of oneself or one's narcissistic desires (Taylor, 1991, p. 82).

Authenticity is "to live genuinely ... to take responsibility for one's actions and to foster true concern for others" (Golomb, 1995, p. 204). It is to act in harmony with one's authentic self "without impeding these processes in others" (Golomb, 1995, p. 205). "Authenticity does not refer to sheer factual life but to the life worth living. [It] cannot be achieved outside a social context ... [it] calls for an ongoing life of significant actions. It is actions that shape our authenticity (Golomb, 1995, p. 201).

Integrity and personal virtue. The Principle of Authenticity in the TARES Test relates to virtue ethics. Instead of focusing on the act, virtue ethics focuses on the actor. "Rather than seeing the heart of ethics in actions or duties, virtue ethics centers in the heart of the agent in his or her character" (Pojman, 1999, p. 158). The goal of life, and thus of one's professional activities, is to live well and achieve excellence (Pojman, 1999, p. 158); “... the unvirtuous (the virtue-indifferent or vicious) life is not worth living" (Pojman, 1999, p. 175). The Principle of Authenticity requires persuaders to evaluate the motivations, intentions, and attitudes that drive their persuasive activities, and to act nobly.

It is important not only to do the right thing, but also to have the requisite dispositions, motivations, and emotions in being good and doing right... Virtue ethics is not only about action but about emotions, character, and moral habit. (Pojman, 1999, p. 158)

Sincerity and genuineness. The Principle of Authenticity as advanced by the TARES test includes also the requirement that professional persuaders should personally believe in the product, service, or cause they are advancing. They should be able to support and advocate it wholeheartedly and in person, including to people they know and love. They should sincerely believe that the product will benefit persuadees, and that the persuasion campaign is truthful, respectful, fair, equitable, and responsible.

Loyalty and independence. The Principle of Authenticity also requires that persuaders examine carefully their multiple and often conflicting loyalties, and to appropriately balance those loyalties in a given situation and context. One must choose to whom or what one will be loyal. Persuaders often are in the dilemma, for example, of having obligations of loyalty to client or employer that seem to conflict with obligations to truthfulness and the well-being of persuadees and of society. In these cases, practitioners must employ their moral discernment to ascertain when the 
demands of these loyalties are perverse, and that independence and adherence to personally held moral principles is required.

Table 2 lists questions for professional persuasive communicators to ask themselves in assessing authenticity in the persuasion.

\section{Respect (for the Persuadee)}

We have discussed the Principle of Respect for the Persuadee in this article at length. It requires that professional persuaders regard other human beings as worthy of dignity, that they not violate their rights, interests, and well-being for raw self-interest or purely client-serving purposes. It assumes that no professional persuasion effort is justified if it demonstrates disrespect for those to whom it is directed. "Human beings ... should not be treated merely as a means to an end; they are to be respected as ends in themselves. Human beings are 'beyond price'" (Jaksa \& Pritchard, 1994, p. 128).

This principle requires further that people should be treated in such a way that they are able to make autonomous and rational choices about how to conduct and arrange their lives according to their own priorities, and that this autonomy should be respected.

When we communicate to influence the attitudes, beliefs, and actions of others, the ethical touchstone is the degree of free, informed, rational, and critical choice significant choice that is fostered by our speaking. (Nilsen, 1966, p. 38, as cited in Griffin, 2000, p. 203)

Christians (1997) suggested that human dignity (the sacredness of life) is a protonorm ("[a principle] that holds true universally," p. 21), that "our human existence is the touchstone of ethics" (p. 25), and that "reverence for life on earth is the philosophical foundation of the moral order" (C. Christians, personal communication, October 14, 2000).

The Principle of Respect for the Persuadee is at the heart of the TARES Test, and is the underlying foundation and motivation for all of its other principles. Persuaders should disseminate truthful messages through equitable appeals with integrity and authenticity and with an eye to the common good because of their respect for the people to whom they are communicating and for all others who will be affected by the persuasion.

Table 3 provides a checklist for moral reflection relating to the Principle of Respect for the Persuadee.

\section{Equity (of the Persuasive Appeal)}

The Equity Principle focuses on the persuasive appeal. In the United States, a large body of law regulates persuasive appeals (laws, for example, 
Table 2

Authenticity (of the Persuader)

Does this action compromise my integrity? Does it conform to my highest principles? Is it true to my best self? Does it conform to my religious convictions?

Does this action arise out of noble intentions and motivations? (Cunningham, 2000.) Although I may have the right to do this, is it the right thing to do?

Do I personally believe in this product, company, service, event, idea, cause? Can I support and advocate it wholeheartedly and in person, including to people I know and love?

Would I openly, publically and personally be an advocate for this cause? Or am I hiding behind the anonymity of a promotional campaign or the work of others?

Do I feel good about being involved in this action? How will I feel if others find out about my participation? Am I willing to take full, open, public, and personal responsibility for this action? (Waltz, 1999, pp. 127-128.)

Do I truly think and believe that the persuadees will benefit (or will be doing the right thing) if they are persuaded to act or think in the ways that this persuasive communication suggests they should?

Is the motive of my action or communication (or of the secret I am keeping) to hurt, deceive, manipulate, or use others merely for my own or my client's purposes (to the detriment and at the expense of the persuadees)?
What is the rule or maxim on which I am acting? Is this rule justifiable? Would I want others to follow the same rule in similar circumstances?

Would I ideally want to live in a world in which people routinely engaged in this type of action? If not, what is my justification for engaging in it myself?

What good reasons and justifications do I have for advocating this product, service, or cause (other than purely self-serving reasons)?

By engaging in this action, am I cooperating with evil or encouraging or requiring others to do so? (Martinson, 1999, pp. 120-122.)

Does this action properly and appropriately (without hurting others) balance my loyalties in this situation to self and conscience, employer, society, humanity, clients, supporters, stockholders, profession and professional colleagues, family, friends, and others who have treated me well? Have I pursued a moral ideal with integrity, despite the behavior of others in society or with whom I work? Am I taking appropriate responsibility for the moral conduct of the organizations with which I work? (Raper, 1999, pp. 123-125.)

What can I do to conduct myself as an authentic person in this situation? 
Table 3

Respect (for the Persuadee)

Is the persuasive appeal made to the decency in people? Have I respected the receivers of this persuasive message by appealing to their higher inclinations and their basic goodness, by not pandering, exploiting, or appealing to their lower or baser inclinations?

Is the persuasive appeal made to persuadees as rational, self-determining beings? Does it facilitate persuadees' capacity to reflect and to make responsible choices about their lives?

Does this action conform to my own religious convictions, and to religious perspectives that people should act with a spirit of caretaking and loving kindness toward others (Christians, Fackler, \& Rotzoll, 1995, p. 19).

What ethical responsibility do I have for the people I am targeting with this persuasion?

What can I do to be more respectful of and more responsible to the people I am persuading, and all others who will be affected by this persuasion?
Does this action or communication respect the persuadee as a human being worthy of dignity and respect? Have I taken the rights, interests, and well-being of others into consideration as much as my own?

Is the quality of this information adequate to the information needs of the persuadees? Does this persuasive message facilitate the persuadees' capacity to act well (i.e., to choose, speak, vote, or purchase well)? (Cunningham, 2000)

Will the persuadees benefit (will they be doing the right thing for themselves and others) if they are persuaded to act or think in the ways that this communication suggests they should?

Does this action promote raw self-interest at the unfair expense of or to the detriment of persuadees?

Does this persuasive appeal contribute to understanding, consideration, reflection, and valid reasoning, and facilitate informed, free-will assent and consent? (Cunningham, 2000)

about deceptive and comparative advertising, celebrity endorsements, etc.), much of which is designed to protect fairness among commercial competitors. The equity principle in the TARES Test considers, instead, fairness to persuadees. It requires that persuaders consider if both the content and the execution of the persuasive appeal are fair and equitable, if persuaders have fairly used the power of persuasion in a given situation or if they have persuaded or manipulated unjustly. Appeals that are deceptive in any way clearly fall outside of the fairness requirement. (Note that although there are conceptual and definitional differences between the terms equity and fairness, they are used interchangeably for our purposes in this discussion.)

The Equity Principle requires either that there be parity between the persuader and persuadee in terms of information, understanding, insight, capacity, and experience, or that accommodations be made to adjust equi- 
tably for the disparities and to level the playing field (the lack of parity must be fairly accounted for and not unfairly exploited). Vulnerable audiences must not be unfairly targeted. Persuasive claims should not be made beyond the persuadees' ability to understand both the context and underlying motivations and claims of the persuader.

\section{Vulnerable audiences must not be unfairly targeted.}

Rawls' (1971) notion of a "veil of ignorance" is a useful conceptual tool for assessing the equity of an appeal. The goal of this approach is to "nullify the effects of specific contingencies which put men at odds and tempt them to exploit social and natural circumstances to their own advantage" (Rawls, 1971, p. 136). The task behind the veil is to find a course of action that will be fair and equitable to all those affected by the decision, and especially to the weaker parties-to ensure "that the interests of some are not sacrificed to the arbitrary advantages held by others" (Cahn \& Markie, 1998 , p. 621). The veil of ignorance requires professional communicators to step conceptually out of their roles as powerful disseminators of persuasive promotional messages and to evaluate the equity of the appeal from the perspective of the weaker parties (their persuadees).

Persuaders also can contemplate issues of fairness and equity by applying the test of reversibility that is expressed simply in the Golden Rule, a concept "basic to so many religious and moral traditions" (Bok, 1989, p. 93).

The Golden Rule has been formulated, the world over, either positively, as an injunction to "do unto others as you would have them do unto you" (Matthew 7:12), or negatively, urging that you not do to others what you would not wish them to do to you, as in the sayings of Confucius or Hillel. In either formulation, the Golden Rule represents not so much a moral value or principle in its own right as a perspective necessary to the exercise of even the most rudimentary morality: that of trying to put oneself in the place of those affected by one's actions, so as to counter the natural tendency to moral myopia (Bok, 1995, pp. 14-15).

As these approaches suggest, it would violate the Principle of Equity to use persuasive appeals that would not seem legitimate if the persuader were on the receiving end of the persuasion.

Table 4 provides a checklist by which the persuasive communicator may consider the Principle of Equity of the Persuasive Appeal in professional practice. 


\section{Social Responsibility (for the Common Good)}

The Principle of Social Responsibility focuses on the need for professional persuaders to be sensitive to and concerned about the wider public interest or common good. It represents an appeal to "responsibility to community over [raw] self-interest, profit, or careerism" (Baker, 1999, p. 75).

The essence of social ethics is to recognize that "humans are accountable to each other, interdependent and not isolated selves" (Christians, et al., 1995, p. 330). Social responsibility ethics recognizes "the human person as a communal being" (Christians, et al., 1995, p. 332). [It] includes "a moral obligation to

Table 4

Equity (of the Persuasive Appeal)

Is the context, nature and execution of this persuasive act fair? Is the power of persuasion used fairly and justly?

Would I feel that the persuasion in this situation was fair, just, ethical and appropriate if it were communicated to me or to people I know and love? Am I doing to others what I would not want done to me or to people I care about?

Is this a persuasion that should not be made, considering the persons and circumstances involved?

Have I unfairly targeted specific (or vulnerable) audiences and made claims outside of their ability to understand the context and underlying claims of the communication? (Patterson \& Wilkins, 1998, p. 63.)

Do the receivers of the message know that they are being persuaded rather than informed?

Has this persuasion taken unfair advantage of a power differential? (Gauthier, 2000)
Is there parity in this situation between the persuader and persuadee in terms of information, understanding, insight, capacity, and experience? If not, have accommodations been made to adjust equitably for the disparities and to level the playing field?

Do persuadees understand what I am claiming my product/service/ company/ position is and can do? Are they able to assess these claims fully and rationally? Do they thoroughly understand the costs and potential harms to themselves and others of what I am advocating?

Is this persuasive appeal sensitive to the needs, interests, concerns, and sensibilities of the persuadees? (Cooper and Kelleher, 2000.)

Does it allow for both reflection and counterargument? (Wilkins and Christians, 2000.)

What can I do to make this persuasive appeal more fair and equitable? 
consider the overall needs of society" (Lloyd, 1991, p.199) ... personal sacrifice for the benefit of others ... and a stewardship toward humanity" (Lloyd, 1991, p.200). Professional communicators are responsible for loyalties to self, profession, organization/employer, and to society, but loyalty to society encompasses all of the others (Parsons, 1993). (Baker, 1999, pp. 75-76)

The Social Responsibility Principle in the TARES Test "assumes that persons in society are interdependent communal beings" and that persuaders "have a responsibility to the societies in which they operate and from which they profit, including obligations of good citizenship in contributing positively to the ... health of society" (Baker, 1999, p. 76). Persuaders acting in harmony with this principle would not promote products, causes, or ideas that they know to be harmful to individuals or to society and will consider contributing their time and talents to promoting products, causes, and ideas that clearly will result in a positive contribution to the common good and to the community of mankind.

Bok (1995) wrote that "All human groups, first of all, and all religious, moral, and legal traditions stress some form of positive duties regarding mutual support, loyalty, and reciprocity" (p. 13); Christians (1999) wrote in a related concept that

All meaningful action is for the sake of community building; the bonding of persons is the epicenter of social formation. Given the primacy of relationships, unless I use my freedom to help others flourish, I deny my own well-being (p.73).

The Social Responsibility Principle in the TARES Test requires moral conduct by professional persuaders at macrolevels as well as microlevels. The principle would demand, for example, that professional persuaders consider the impact of their communications on society if only a few wellfinanced and privileged voices are able to dominate the marketplace of ideas and distort the balance of debate on important societal issues (Moyers, 1999).

These are important questions because critics insist that public relations has been used as manipulation by powerful political, economic, and social interests intent on achieving their own narrow goals at the expense of the greater common good. In fact, it is sometimes alleged, public relations as it is practiced is too frequently dysfunctional for society in that it serves primarily to disrupt the "proper" functioning of the marketplace of ideas. (Martinson, 1998, p. 146)

As an example of a macrolevel concern for the common good, Martinson (1998) wrote that distributive and social justice require that public relations practitioners "must take seriously the challenge of defining how they can positively serve the traditionally under-represented in society" (p. 148). 
Meeting the demands of the Principle of Social Responsibility ultimately comes down to the issue that is at the heart of all the principles in the TARES Test: the question of respect, respect for individuals and for society (Martinson, 1998, p. 149, citing Jaksa \& Pritchard, 1994).

Although political and moral philosophers have differed on the precise content of the common good and how to promote it, there is a core meaning that the welfare of all citizens, rather than that of factions or special interests, should be served impartially. Moreover, it is a normative principle, not just the majority results of an opinion poll or voting. The common good cannot be understood statistically, but is a "fundamental concept of social morality" (Diggs, 1973, p. 284, italics added; Christians, 1999, p. 68).

Table 5 suggests some questions professional practitioners might ask themselves in considering application of this principle.

\section{TARES Test As A Set of Prima Facie Duties}

The TARES Test has been presented here as a set of prima facie duties for professional persuasion (i.e., public relations, advertising, promotional campaigns, and commercial information). Prima facie duties are basic moral obligations (Ross, 1930), the understanding of which may "counter the natural tendency to moral myopia" (Bok, 1995, p. 15). Moral myopia arises from raw self-interest or particularity. As Pojman (2000) said, there is always a tension between particularity and universality (see Figure 2 illustrating this point). Because public relations and advertising are inherently particular (professionals serving the interests of clients and of self), moral safeguards must be put into place to balance the excesses and harm that can result from rampant particularity.

The five principles in the TARES Test are interrelated moral safeguards (as the overlapping questions in the reflection and application tables demonstrate); the principles are mutually supporting and validating (e.g., being truthful demonstrates respect for others, respect for others leads the authentic practitioner to social responsibility, the authentic practitioner acts equitably and thus respectfully, the equitable appeal is truthful and socially responsible, etc.).

Ideally, all prima facie duties must be honored at all times in all of one's actions. There may conceivably be times, however, in which adherence to one principle will cause one to violate another. For example, truthfulness may sometimes be disrespectful of individuals or result in inequities (see Martinson, 2000, on this problem for journalists).

When prima facie duties conflict, a moral dilemma emerges. Kidder (1995) used the term ethical dilemma "to stand for those right-versus-right situations where two core moral values come into conflict" as distin- 
Table 5

Social Responsibility (for the Common Good)

Does this action recognize the interdependency of persons in society, of persons as communal beings? (Christians et. al., 1995, p. 332) Is the action/

communication responsible to individuals, society, the public, and the public interest?

Will the product or issue I am promoting cause harm to individuals or to society? Does this action conform to the ethical requirement to do no unnecessary harm or to prevent harm?

Has this action's potential negative impact on individuals and the common good been taken into account and responded to appropriately?

Does this persuasive communication promote (or strain) understanding and cooperation among constituent groups of society? Does it enhance or deplete public trust? (Bok, 1989, p. 26)

Will this action (or not having this information) cause disproportionate harm to any person, group, or interest? (Fitzpatrick \& Gauthier, 2000)
Does this action take responsibility to promote and create the kind of world and society in which persuaders themselves would like to live with their families and loved ones? (Baker, 1999)

Have I legitimately and fairly participated in the marketplace of ideas such that competing ideas fairly can be heard and considered by the public? Have I considered the responsibility to fairly represent issues and to allow and foster public consideration of alternative views? (Moyers, 1999)

Have I taken seriously the challenge of defining how I can positively serve the interests and views of the traditionally underrepresented in society? (Martinson, 1998, p. 148)

Have I unfairly stereotyped constituent groups of society in this promotion/ communication campaign?

Does this persuasive communication elucidate issues, dispel confusion and ignorance, and encourage public dialogue based on truthful information?

(Cunningham, 2000)

guished from "right-versus-wrong issues that produce what can usefully be called moral temptations" (Kidder, 1995, pp. 113-114). "A moral dilemma occurs when a choice is required among actions that meet competing commitments or obligations, but there are good reasons for and against each alternative" (Fitzpatrick \& Gauthier, this issue, p. 207).

Bonhoeffer (1962), for example, wrote about the problem of competing commitments and obligations with regard to truth telling, holding that truth is sensitive to context (see Martinson, 2000, on Bonhoeffer and journalism). "Every utterance or word lives and has its home in a particular environment.... Telling the truth ... [has] respect for secrecy, confidence, and concealment" (Bonhoeffer, 1962, pp. 329, 334). This does not mean that 
Particularity Universality

(Sole focus on well-being of

self/client/employer.)

(Sole focus on well-being of

persuadees/society.)

Figure 2 Particularity/universality continuum.

truth is relative or that it "can and may be adapted to each particular situation in a way which completely destroys the idea of truth and narrows the gap between truth and falsehood, so that the two become indistinguishable" (Bonhoeffer, 1962, p. 329). It does mean that in applying principles to situations one must take the context into consideration.

Martinson (1997-1998) suggested that there is a difference between situational ethics and taking the nuances of the situation into account in one's moral deliberations. In the latter, one applies "accepted ethical principles ... to particular acts" (Martinson, 1997-1998, p. 42).

\section{In applying principles one must [consider] context.}

If practitioners are to behave ethically in the "real world," it is essential they be able to identify the basic principles and values that are universally relevant to defining what will be acceptable conduct in persuasive communication. They must then apply those principles and values under specific circumstances. It is vital that they recognize the difference between doing that and practicing situational ethics (Martinson, 1997-1998, p. 43).

In situations in which prima facie duties conflict, one must decide which of the principles has the greatest moral claim on one in a given context. Violation of one of the principles can be justified only by well-motivated adherence to another of the prima facie duties. Fitzpatrick and Gauthier (this issue) have written on this topic that

It is important to recognize that these are prima facie, and not absolute, principles. They are principles that hold generally unless they conflict with one another. When only one of the principles is implicated in a moral choice, that principle should be taken as the controlling guideline for ethical conduct. However, moral dilemmas often involve conflicts between the principles. In these cases, the decision maker must employ his or her own values, moral intuition, and character to determine which principle is most important and most controlling in the particular context (p.207-208). 
Morality, as Pojman observed, is sometimes ambiguous. "When you really have a dilemma, you must use your moral intuition" (Pojman, 2000). Kidder (1995) wrote similarly that "there can be no formula for resolving dilemmas, no mechanical contraption of the intellect that churns out the answer" (p. 176).

The more we work with these principles, the more they help us understand the world around us and come to terms with it.... In the act of coming to terms with the tough choices, we find answers that not only clarify the issues and satisfy our need for meaning but strike us as satisfactory resolutions. (Kidder, 1995, p. 176)

The authentic persuasive communicator will thoughtfully and successfully traverse these murky waters by keeping in mind the pivotal Principle of Respect for persuadees (and all others affected by the persuasion) on which the TARES Test is grounded, and by recognizing that "the only acts that are morally good are those that proceed from a good motive" (Ross, 1930, p. 4).

\section{Conclusions}

It was our goal in this article to identify the legitimate and moral end of professional persuasive communications. We argued that although professional persuasion is a means to an immediate instrumental end (such as increased sales or enhanced corporate image), ethical persuasion must rest on or serve a deeper, morally based final (or relative last) end.

Toward that goal, we have proposed a five-part test that defines the moral boundaries of persuasive communications and serves as a set of action-guiding principles directed toward a moral consequence in persuasion. We suggest that these five principles, taken together, comprise the legitimate end of professional persuasive communications and that these communications are ethical and morally justified if they adhere to the principles of Truthfulness (of the message), Authenticity (of the persuader), Respect (for the persuadee), Equity (of the persuasive appeal), and Social Responsibility (for the common good).

\section{References}

Andersen, K. E. (1978). Persuasion: Theory and practice. Boston: Allyn \& Bacon.

Baker, S. (1999). Five baselines for justification in persuasion. Journal of Mass Media Ethics, 14, 69-81.

Bok, S. (1989). Lying: Moral choice in public and private life. New York: Vintage.

Bok, S. (1995). Common values. Columbia: University of Missouri Press.

Bonhoeffer, D. (1962). Ethics. New York: Macmillan. 
Cahn, S., \& Markie, P. (1998). Ethics, history, theory, and contemporary issues. New York: Oxford University Press.

Christians, C. (1997). The common good and universal values. In J. Black (Ed.), Mixed news: The public/civic/communitarian journalism debate (pp. 18-35). Mahwah, NJ: Lawrence Erlbaum Associates, Inc.

Christians, C. (1999). The common good as first principle. In T. L. Glasser (Ed.), The Idea of public journalism (pp. 67-84). New York: Guilford.

Christians, C., Fackler, M., \& Rotzoll, K. (1995). Media ethics: Cases E moral reasoning (4th ed). New York: Longman.

Cooper, T., \& Kelleher, T. (2000). Remarks in discussion among Fellows. Colloquium 2000: The Ethics of Persuasion. Park City, Utah, October 10-14, 2000.

Cunningham, S. B. (October 10-14, 2000). Remarks in discussion among Fellows. Colloquium 2000: The Ethics of Persuasion. Park City, Utah.

Cutlip, S. M. (1994). The unseen power: Public relations. A history. Mahwah, NJ: Lawrence Erlbaum Associates, Inc.

Cutlip, S. M., Center, A. H., \& Broom, G. M. (1994). Effective public relations. Englewood Cliffs, NJ: Prentice Hall.

Deaver, F. (1990). On defining truth. Journal of Mass Media Ethics, 5, 168-177.

DeFleur, M. L., \& Dennis, E. E. (1998). Understanding mass communication. Boston: Houghton Mifflin.

Diggs, B. J. (1973). The common good as reason for political action. Ethics, 83, 283-284.

Fagothey, A. (1976). Right and reason: Ethics in theory and practice. St. Louis, MO: Mosby.

Fitzpatrick, K., \& Gauthier, C. (October 10-14, 2000). Remarks in discussion among Fellows. Colloquium 2000: The Ethics of Persuasion. Park City, Utah.

Gaffney, J. (1979). Newness of life. New York: Paulist Press.

Golomb, J. (1995). In search of authenticity: From Kierkegaard to Camus. London: Routledge \& Kegan Paul.

Griffin, E. (2000). A first look at communication theory (4th ed.). Boston: McGraw-Hill.

Grunig, J. E., \& Hunt, T. (1984). Managing public relations. Fort Worth, TX: Holt, Rinehart \& Winston.

Gauthier, C. (October 10-14, 2000). Remarks in discussion among Fellows. Colloquium 2000: The Ethics of Persuasion. Park City, Utah.

Hugo, V. (1997). Les Miserables. New York: Knopf. (Original work published 1862)

International Association of Business Communicators. (2000). International association of business communicators code of ethics for professional communicators. Retrieved December 29, 2000, from the World Wide Web: http:/ / www.iabc.com/ members/joining/code.htm

Jaksa, J. A., \& Pritchard, M. S. (1994). Communication ethics: Methods of analysis. Belmont, CA: Wadsworth.

Kidder, R. M. (1995). How good people make tough choices: Resolving the dilemmas of ethical living. New York: Morrow.

Klaidman, S., \& Beauchamp, T. L. (1987). The virtuous journalist. New York: Oxford University Press.

Lambeth, E. B. (1986). Committed journalism: An ethic for the profession. Bloomington, IN: Indiana University Press. 
Langan, T. (1992). Tradition and authenticity in the search for ecumenic wisdom. Columbia, MO: University of Missouri Press.

Lloyd, S. (1991). A criticism of social responsibility theory: An ethical perspective. Journal of Mass Media Ethics, 6, 199-209.

Martinson, D. L. (1996, August). Thomas Schindler and the social dimension of ethics: Serious questions for the public relations 'culture'. Paper presented to the Public Relations Division of the Association for Education in Journalism and Mass Communication, Anaheim, CA.

Martinson, D. L. (1996-1997). Truthfulness in communication is both a reasonable and achievable goal for public relations practitioners. Public Relations Quaterly, 41(4), 42-45.

Martinson, D. L. (1997-1998, Winter). Public relations practitioners must not confuse consideration of the situation with "situational ethics." Public Relations Quarterly, 42(4),39-43.

Martinson, D. L. (1998). A question of distributive and social justice: Public relations practitioners and the marketplace of ideas. Journal of Mass Media Ethics, 13,141151.

Martinson, D. L. (1999). The public interest must take precedence. Journal of Mass Media Ethics, 14, 120-122.

Martinson, D. L. (2000). Dietrich Bonhoeffer and communicating "the truth": Words of wisdom for journalists. Journal of Mass Media Ethics, 15, 5-16.

Middleton, K. R., \& Chamberlin, B. F. (1994). The law of public communication. New York: Longman.

Montgomery, J. (1978, August 1). In public relations, ethical conflicts pose continuing problems. Wall Street Journal, pp. 1, 14.

Moyers, B. (1999). Free speech for sale. In Public Affairs Television (Producer), Free speach for sale. (Available from Films for the Humanities \& Sciences, Princeton, NJ, 1-800-257-5126).

National Communication Association. (2000). NCA credo for ethical communication. Media Ethics: The Magazine Service Mass Communications Ethics, Spring 2000, 11(2), 39.

Nilsen, T. R. (1966). Ethics of speech communication. Indianapolis, IN: Bobbs-Merrill.

Parsons, P. (1993). Framework for analysis of conflicting loyalties. Public Relations Review, 19(1), 49-57.

Patterson, P., \& Wilkins, L. (1998). Media ethics: Issues \& cases (3rd ed.). Boston: McGraw-Hill.

Pember, D. R. (1981). Mass media law. Dubuque, IA: Brown.

Pojman, L. (1999). Ethics: Discovering right and wrong. Belmont, CA: Wadsworth.

Pojman, L. (October 10-14, 2000). Remarks in discussion among Fellows. Colloquium 2000: The Ethics of Persuasion. Park City, Utah.

Pontifical Council for Social Communications. (1997). Ethics in advertising. Boston: Pauline Books \& Media.

Public Relations Society of America. (2000). Public Relations Society of America member code of ethics. Retrieved December 29, 2000, from the World Wide Web: http:/ /prsa.org/profstd.html

Raper, M. (1999). Expose myths and focus on the miracle. Journal of Mass Media Ethics, 14, 123-125. 
Rawls, J. (1971). A theory of justice. Cambridge, MA: Harvard University Press.

Ross, W. D. (1930). The right and the good. Cambridge: Hackett.

Society of Professional Journalists. (1996). SPJ Code of Ethics. Retrieved December 29, 2000, from the World Wide Web: http:/ / spj.org/ethics/code.htm

Taylor, C. (1991). The ethics of authenticity. Cambridge, MA: Harvard University Press.

Virginia State Board of Pharmacy v. Virginia Citizens Consumer Council, Inc., 425 U.S. 748 (1976).

Waltz, S. L. (1999). A list of acid tests. Journal of Mass Media Ethics, 14, 127-128.

Wells, W., Burnett, J., \& Moriarty, S. (1992). Advertising: Principles and practice. Englewood Cliffs, NJ: Prentice Hall.

Wilkins, L., \& Christians, C. (October 10-14, 2000). Remarks in discussion among Fellows. Colloquium 2000: The Ethics of Persuasion. Park City, Utah. 
Copyright of Journal of Mass Media Ethics is the property of Lawrence Erlbaum Associates and its content may not be copied or emailed to multiple sites or posted to a listserv without the copyright holder's express written permission. However, users may print, download, or email articles for individual use. 